\title{
Advanced Dead Weighted Loading Universal Testing Machine
}

\author{
正 今村 仙治（日大 工）

\section{Senji Imamura , Nihon University}

\section{1.はじめに}

精密引張試験機として一般的に用いられているものはネ ジ式 (Instron type)である。試験機および試験方法は試験 結果が理論の構築の元になるので重要である。

本報では重り式荷重制御をべースとし、これを発展させ た荷重制御方法を用いた万能試験機を開発した。特徵とし ては試験片のひずタにより制御を行うこと、微少荷重区間 において変形が静止するまでの時間の测定および引張速度 を 2 段階で行えることである。この試験機の概要と測定結 果について述べる。

\section{2. 発展型重り式万能試験機の制御法}

Fig.1 に発展型重り式万能試験機のフローチャートを示 す。制御はパーソナルコンピーュターにより行われる。荷 重制御部(S1～S3) とひずみ検出部 $(\mathrm{S} 4$ ～S 9) で構成されて いる。小さな荷重を階段的に試験片に負荷する機構となっ ており、ひずみは試験片に貼付したストレーングージによ り検出され、さらにひずみの変化量がある範囲内に達しな ければ(S8)、いつまでも所定荷重が負荷され続ける。荷重 が負荷され初めてから、ひずみの安定確認時間(S6)を含め 荷重更新指令までの時間を測定し、逐次データを保存する。 この操作を破壊近傍まで行う。駆動モーターはパルス制御 を行うことにより $0.1 \mu \mathrm{m}$ の精度で引張試験を行った。

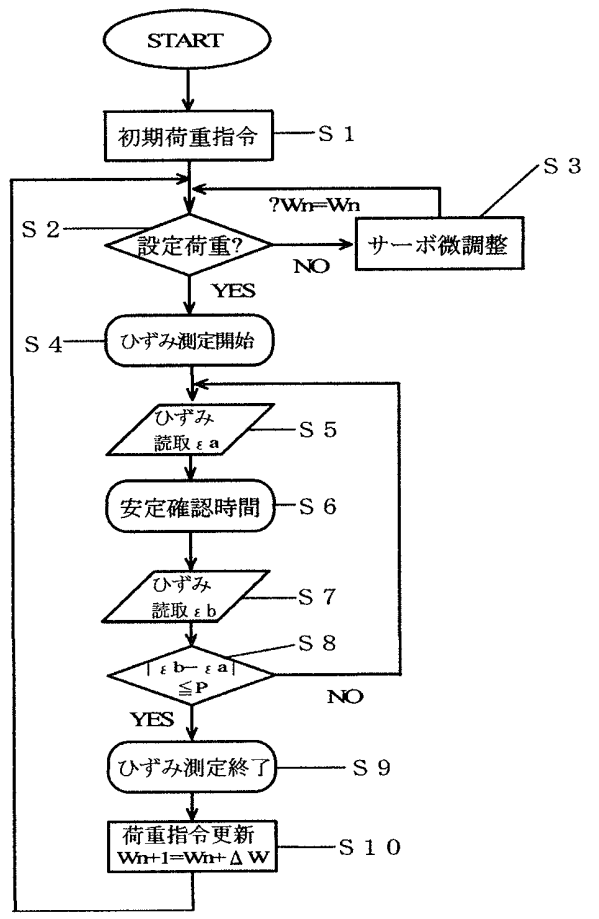

Fig.1 Flow chart of the control method
Fig.2 に Fig.1 に示した荷重指令(S 1)から荷重更新指令 (S 10 )までの間の荷重 $\mathrm{W}$ と時刻 $\mathrm{t}$ および引張速度 $\mathrm{V}$ との 関係を示す。点 $\mathrm{A}(\mathrm{n}-1)$ から所定の荷重(点 $\mathrm{Bn})$ まで引張速 度 $\mathrm{V}_{1}$ で引張り、所定の荷重(点 $\mathrm{Bn}$ )に達したら点 $\mathrm{An}$ まで引 張速度 $V_{2}$ で引張る。荷重一定の状態でひずみの値が静止状 態になったら、次の所定の荷重(点 $\mathrm{Bn}+1)$ になるまで引張る。 時刻 te 仕点 $\mathrm{A}(\mathrm{n}-1)$ と点 $\mathrm{Bn}$ との間の時間、時刻 th は点 $\mathrm{Bn}$ と点 $\mathrm{An}$ との閒の時間、時刻 $\Delta t$ は点 $\mathrm{A}(\mathrm{n}-1)$ と点 $\mathrm{An}$ との間の時間をそれぞれ示す。

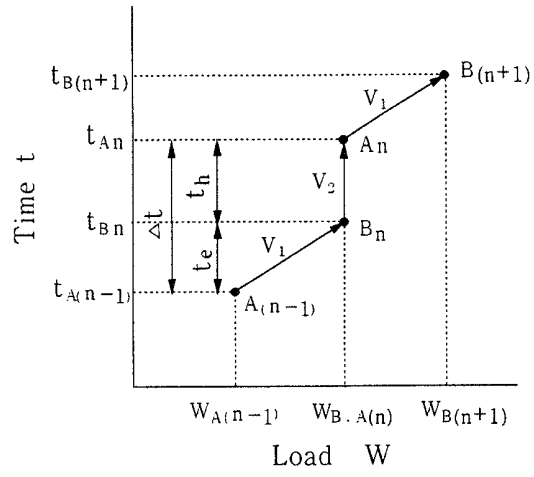

Fig.2 The relationship between load $\mathrm{W}$ and time $\mathrm{t}$ and tension speed V.

\section{3. 発展型重り式万能試験機による試験結果} 本試験機の制御のためのパラメータの説明を行う。

1. Start Load (N) --.--試験開始時の荷重設定

2. Stop Load (N) -..---試験終了時の荷重設定

3. Step Stress $\sigma \mathrm{s}(\mathrm{MPa})$-..--階段応力の設定

4. Loading Speed $V_{1}(\mathrm{~mm} / \mathrm{min}) \cdots$ 荷重負荷速度の設定

5. Load on time(s) ……設定の荷重に達した時からひずみ測 定開始までの時間設定

6. Reducing Speed $\mathrm{V}_{2}(\mathrm{~mm} / \mathrm{min})$--減速速度の設定

7. Load Hold time(s) -..-ひずみが所定の值に達したかど うかを計測する時間インターバルの設定 8.Strain Stable rate $(\mu)$-...-ひずみが安定したと判断する ときのひずみの変化量の設定

9 .Load Near (N) - - 設定荷重の手前から減速速度開始する ときの荷重設定

Table1 に測定された data の一部を示す。No は測定回 数、TIME は測定時の時間、 time は測定時の時刻、Load は 荷重、Position はクロスヘッドの位置、Number はモータ 制御時のパルス数、 $\varepsilon 1 \sim \varepsilon 4$ は試験片中央部表面上、9 0 度間隔に貼ったストレーンダージのひずみをそれぞれ示す。 測定回数の No の中で奇数番号は図 2 中の点 $\mathrm{A} の$ data で、 
Table 1 Experimental data

\begin{tabular}{|c|c|c|c|c|c|c|c|c|c|}
\hline No & $\begin{array}{c}\text { TIME } \\
\mathrm{s}\end{array}$ & $\begin{array}{c}\text { time } \\
\mathrm{s}\end{array}$ & $\begin{array}{c}\text { Load } \\
\mathrm{N}\end{array}$ & $\begin{array}{c}\text { Position } \\
\mathrm{mm}\end{array}$ & $\begin{array}{c}\text { Number } \\
\text { puls }\end{array}$ & $\begin{array}{c}\varepsilon 1 \\
\mu\end{array}$ & $\begin{array}{c}\varepsilon 2 \\
\mu\end{array}$ & $\begin{array}{c}\varepsilon 3 \\
\mu\end{array}$ & $\begin{array}{c}\varepsilon 4 \\
\mu\end{array}$ \\
\hline 0 & $9: 12: 43$ & 9 & 932 & 36 & 371 & 7 & 9 & 9 & 5 \\
\hline 1 & $9: 12: 53$ & 19 & 961 & 38 & 390 & 3 & 6 & 6 & 1 \\
\hline 2 & $9: 13: 04$ & 31 & 1196 & 54 & 550 & 17 & 26 & 25 & 16 \\
\hline 3 & $9: 13: 15$ & 41 & 1187 & 55 & 560 & 15 & 23 & 24 & 14 \\
\hline 4 & $9: 13: 27$ & 52 & 1432 & 71 & 724 & 24 & 37 & 36 & 23 \\
\hline 5 & $9: 13: 36$ & 63 & 1432 & 72 & 733 & 22 & 34 & 35 & 20 \\
\hline 6 & $9: 13: 48$ & 74 & 1667 & 87 & 892 & 37 & 50 & 51 & 36 \\
\hline 7 & $9: 13: 58$ & 84 & 1657 & 89 & 904 & 35 & 49 & 50 & 34 \\
\hline 8 & $9: 14: 10$ & 96 & 1912 & 105 & 1072 & 50 & 61 & 63 & 47 \\
\hline 9 & $9: 14: 20$ & 106 & 1912 & 107 & 1089 & 51 & 61 & 63 & 47 \\
\hline 10 & $9: 14: 31$ & 117 & 2148 & 122 & 1237 & 61 & 72 & 73 & 58 \\
\hline$\cdot$ & $\cdot$ & $\cdot$ & - & $\cdot$ & - & $\cdot$ & $\cdot$ & $\cdot$ & $\cdot$ \\
\hline$\cdot$ & $\cdot$ & - & $\cdot$ & $\cdot$ & $\cdot$ & $\cdot$ & $\cdot$ & $\cdot$ & $\cdot$ \\
\hline
\end{tabular}

偶数番号は Fig.2 中の点 B の data である。

\section{1 荷重履歴の検出}

Fig.3 に同一試験片に対して 3 度引張試験行ったときの 忍力とひずみの関係を示す。初回は $65 \mathrm{MPa}$ まで荷重を加 えた後除荷。2 回目は $160 \mathrm{MPa}$ まで荷重を加えた後除荷。 3 回目は破壊まで荷重を加えた。応力ーひずみ曲線上では 荷重履歴の様子はみられない。

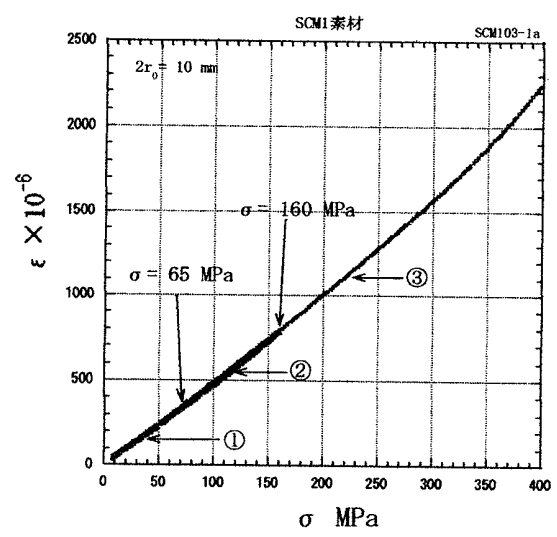

Fig.3 The relationship between stress $\sigma$ and strain $\varepsilon$

Table 2 に応力と時刻の関係の解析の一例を示す。Noは 測定回数、 time は測定時の時刻、te と th 及び $\Delta \mathrm{t}$ は Fig.2 で示したの時刻をそれぞれ示す。Load 及び $\sigma$ は測定時の荷 重と応力を示す。

Fig.4 に 2 回目と 3 回目の荷重を加えたときの忘力 $\sigma$ と 時刻 $\mathbf{t}$ の関係を同時に示す。曲線( I ) は応力 $\sigma$ と時刻 $\mathbf{t}$ の関 係であり、65MPa で別の曲線となり変化が顕著に見られる。

曲線(II)は Table 2 で示した応力 $\sigma$ と時刻 te との関係を 表す。65MPa の位置と $160 \mathrm{MPa}$ の位置が明瞭に見られ、 過去にこれらの応力が付与されたことが検出できる。

Table 2 Analysis sample of stress $\sigma$ and time $t$

\begin{tabular}{|c|c|c|c|c|c|c|c|}
\hline NO & $\begin{array}{c}\text { tA } \\
s\end{array}$ & $\begin{array}{c}\mathrm{tB} \\
\mathrm{s}\end{array}$ & $\begin{array}{c}\text { te } \\
\mathrm{s} \\
\end{array}$ & $\begin{array}{c}\text { th } \\
\text { s }\end{array}$ & $\begin{array}{c}\Delta t \\
s\end{array}$ & $\begin{array}{c}\text { Load } \\
\mathrm{N}\end{array}$ & $\begin{array}{c}\sigma \\
\mathrm{MPa}\end{array}$ \\
\hline 1 & 19 & 31 & 12 & 10 & 22 & 961 & 10.1 \\
\hline 3 & 41 & 52 & 12 & 10 & 22 & 1187 & 12.5 \\
\hline 5 & 63 & 74 & 11 & 11 & 22 & 1432 & 15.1 \\
\hline 7 & 84 & 96 & 11 & 10 & 21 & 1657 & 17.4 \\
\hline 9 & 106 & 117 & 12 & 10 & 22 & 1912 & 20.1 \\
\hline 11 & 127 & 138 & 11 & 10 & 21 & 2138 & 22.5 \\
\hline 13 & 148 & 159 & 11 & 10 & 21 & 2373 & 25.0 \\
\hline 15 & 180 & 190 & 11 & 21 & 32 & 2618 & 27.5 \\
\hline 17 & 200 & 211 & 10 & 10 & 20 & 2864 & 30.1 \\
\hline 19 & 221 & 231 & 11 & 10 & 21 & 3099 & 32.6 \\
\hline 21 & 252 & 261 & 10 & 21 & 31 & 3334 & 35.1 \\
\hline 23 & 271 & 281 & 9 & 10 & 19 & 3570 & 37.6 \\
\hline$\therefore$ & 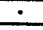 & 5 & t & . & - & $\cdot$ & $\dot{\square}$ \\
\hline . & $\cdot$ & $\div$ & 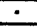 & 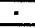 &. & $\div$ & ${ }^{\circ}$ \\
\hline
\end{tabular}

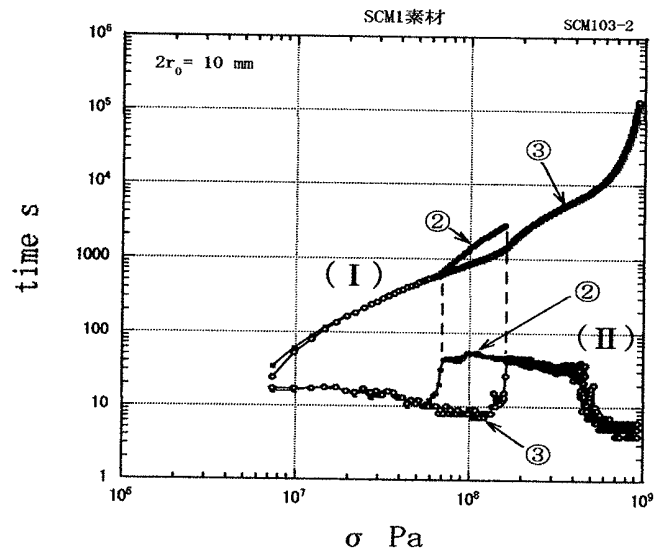

Fig.4 The relationship between stress $\sigma$ and time t 3.2 復元ひずみの検出

Table 3 に応力とひずみの解析結果の一部を示す。 $\varepsilon$ は測 定時のひずみ、 $\varepsilon$ e、 $\varepsilon$ h、及び $\Delta \varepsilon$ は Fig.2 おいて te、th、 及び $\Delta \mathrm{t}$ に相当する位置にお汸るひずみの值を示す。

Fig.5 に応力 $\sigma$ とひずみ $\varepsilon$ の関係を示す。応力 $\sigma$ 一ひず み $\varepsilon \mathbf{h}$ 曲線においてひずみ $\varepsilon \mathbf{h}$ を復元ひずみと呼ぶ。650 $\mathrm{MPa}$ 付近で復元ひずみの值が最大值を示している。このグ ラフは縦弾性係数を求めるために用いられる。

Table 3 Analysis sample of stress $\sigma$ and strain $\varepsilon$

\begin{tabular}{|c|c|c|c|c|c|c|c|}
\hline NO & $\begin{array}{c}\varepsilon_{\mathrm{A}} \\
\mu\end{array}$ & $\begin{array}{c}\varepsilon_{\mathrm{B}} \\
\mu\end{array}$ & $\begin{array}{c}\varepsilon_{\mathrm{e}} \\
\mu\end{array}$ & $\begin{array}{c}\varepsilon_{\mathrm{h}} \\
\mu\end{array}$ & $\begin{array}{c}\Delta \varepsilon \\
\mu\end{array}$ & $\begin{array}{c}\text { Load } \\
\mathrm{N}\end{array}$ & $\begin{array}{c}\sigma \\
\mathrm{MPa}\end{array}$ \\
\hline 101 & 663 & 677 & 16 & -5 & 10 & 12768 & 134.4 \\
\hline 103 & 676 & 691 & 15 & -1 & 14 & 12994 & 136.7 \\
\hline 105 & 690 & 707 & 15 & -1 & 14 & 13239 & 139.3 \\
\hline 107 & 702 & 720 & 17 & -5 & 12 & 13474 & 141.8 \\
\hline 109 & 715 & 729 & 19 & -5 & 14 & 13710 & 144.3 \\
\hline 111 & 724 & 737 & 14 & -5 & 9 & 13945 & 148.7 \\
\hline 113 & 737 & 752 & 13 & 0 & 13 & 14180 & 149.2 \\
\hline 115 & 746 & 768 & 15 & -5 & 10 & 14426 & 151.8 \\
\hline 117 & 763 & 776 & 22 & -5 & 16 & 14661 & 154.3 \\
\hline 119 & 774 & 792 & 13 & -2 & 11 & 14886 & 156.6 \\
\hline 121 & 789 & 804 & 19 & -3 & 16 & 15132 & 159.2 \\
\hline 123 & 798 & 818 & 14 & -6 & 9 & 15367 & 161.7 \\
\hline- & - & - & - & - & - & - & - \\
\hline & - & - & - & - & - & & - \\
\hline
\end{tabular}

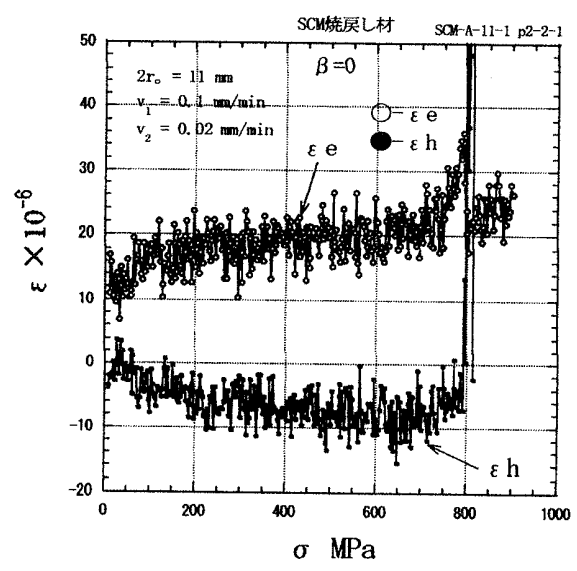

fig.5 The relationship between stress $\sigma$ and strain $\varepsilon$

4. まとめ

新しく開発した発展型重り式万能試験機の概要と試験結 果の一部の説明を行った。本機の特徽は引張試験に時間の ファクターを取り入れることにより、材料の荷重履歴等が 測定可能となったことである。降伏点や縦弾性係数の測定 法についても報告を行う予定である。 